\title{
Suomalaisten peltokasvien energiatase ja nettoenergia
}

\author{
Hannu J. Mikkola ja Jukka Ahokas \\ Helsingin yliopisto, Agroteknologian laitos, Koetilantie 3, 00014 Helsingin yliopisto \\ hannu.j.mikkola@helsinki.fi, jukka.ahokas@helsinki.fi
}

\section{Tiivistelmä}

Energiakasvien viljely pellolla on yksi mahdollisuus tuottaa uusiutuvaa bioenergiaa. Viljelyn järkevyyttä harkittaessa tulee ottaa huomioon taloudelliset ja ympäristötekijät sekä viljelyn energiatalous. Tässä tutkimuksessa selvitettiin ohran, vehnän, rypsin, säilörehunurmen, ruokohelven, perunan ja sokerijuurikkaan energiatase ja nettoenergia. Energiatase on sadon energiasisällön ja sadon aikaansaamisen käytetyn energiapanoksen suhde. Mitä suurempi suhdeluku on, sitä enemmän energiaa saadaan suhteessa käytettyyn energiapanokseen. Nettoenergia puolestaan ilmaisee, kuinka paljon energiaa hehtaarilta saadaan, kun tuotantoon käytetyt energiapanokset on vähennetty sadon energiasisällöstä. Molempia lukuja tarvitaan arvioitaessa energiakasvien kilpailukykyä. Korkea energiasuhde ei yksin riitä, koska pinta-alaa energian tuottamiseen on rajoitetusti.

Tarkasteluun otettiin vain sellaisia kasveja, joiden tiedetään kokemuksen perusteella soveltuvan talousviljelyyn. Ohran, vehnän, rypsin, säilörehunurmen ja ruokohelven energiasuhde ja nettoenergia laskettiin typpilannoituksen funktiona, koska lannoitetypen valmistus on viljelyn suurin yksittäinen energiapanos. Osaa kirjallisuudessa esitetyistä typpivastefunktioita skaalattiin alaspäin, koska funktioiden käyttö sellaisenaan olisi johtanut paljon todellisuudessa saatavia korkeampiin satoihin. Perunan ja sokerijuurikkaan energiasuhde ja nettoenergia laskettiin vain yhdellä typpilannoitusmäärällä, koska niille ei ollut käytettävissä typpivastefunktioita.

Kaikista tutkituista kasveista voitiin todeta yhteisesti, että energiasuhde oli korkeimmillaan, jos typpeä käytettiin keskimääräisiä suosituksia vähemmän. Toisaalta suurin nettoenergia saatiin käyttämällä typpilannoitetta suositeltuja määriä enemmän. Käytännön viljelyä taasen ohjaa taloudellinen optimi, joka on typen osalta tämän hetken hintasuhteilla lähempänä energiasuhteen optimia kuin nettoenergian optimia.

Ruokohelven energiasuhde oli selvästi kaikkein korkein ja ruokohelpi tuotti parhaimmillaan yhtä paljon nettoenergiaa kuin sokerijuurikas. Ruokohelven energiasuhde oli $11-13$, kun typpilannoitus oli $60-80 \mathrm{~kg} / \mathrm{ha}$. Korkeampi energiasuhde saavutettiin pienemmällä lannoituksella. Ohran, kevätvehnän ja rypsin energiasuhteet olivat 3 - 5 käytettäessä normaaleja typpilannoitusmääriä. Perunan ja sokerijuurikkaan energiasuhde oli korkeampi kuin viljojen ja rypsin, mutta systeemin rajaus oli sellainen, että se suosi perunaa ja sokerijuurikasta. Tarkastelun päättyessä peruna ja sokerijuurikas olivat aumassa pellon laidalla ja sadon säilyttäminen käyttökelpoisena olisi edellyttänyt energiaa kuluttavaa prosessointia tai varastointia lämpöeristetyssä ja ilmastoidussa varastossa. Lisäksi peruna ja sokerijuurikas ovat vaateliaita kasveja verrattuna viljoihin ja ruokohelpeen.

Ruokohelven parhaat nettoenergiasadot olivat $110-120 \mathrm{GJ} \mathrm{ha}^{-1}$, mutta realistinen sato voisi olla 80 - $90 \mathrm{GJ} \mathrm{ha}^{-1}$. Se on jonkin verran enemmän kuin tyypillisen suomalaisen pientalon vuotuinen lämmöntarve $(20000 \mathrm{kWh}=72 \mathrm{GJ})$. Viljojen nettoenergiasadot olivat parhaimmillaan $50-55 \mathrm{GJ}^{-\mathrm{ha}^{-1}} \mathrm{ja}$ rypsin $30-35 \mathrm{GJ} \mathrm{ha}^{-1}$.

Asiasanat: bioenergia, energiakasvi, energiasuhde 


\section{Johdanto}

Tiedotusvälineissä energiakasveja ehdotetaan toistuvasti fossiilisten polttoaineiden korvaajaksi. Viljelyn hyödyt ja haitat pitää kuitenkin tutkia ennen laajamittaisen viljelyn aloittamista, koska viljelyyn tarvitaan energiaa ja viljely kuormittaa maata, vesistöjä ja ilmaa. Ei ole itsestään selvää, että uusiutuva energia on energiatehokkaampaa ja ympäristöystävällisempää kuin fossiilinen polttoaine. Peltobiomassa kilpailee ensisijaisesti puun kanssa. Turve luokitellaan tällä hetkellä fossiiliseksi polttoaineeksi, mutta sen käyttö jatkunee lähitulevaisuudessa ennallaan, koska turve on halvin voimalaitospolttoaine.

Energiakasveista voidaan valmistaa etanolia tai biodieseliä, tai ne voidaan polttaa lämmöksi. Viljeltävä kasvi valitaan käyttötarkoituksen mukaan ja viljelyssä pyritään tuottamaan mahdollisimman paljon biomassaa mahdollisimman pienellä panoksella. Tuotoksen (Output) ja panoksen (Input) suhdetta kutsutaan energiasuhteeksi ja sen tulisi olla mahdollisimman suuri. Koska viljelyyn käytettävissä maa-ala on rajallinen, energiakasvin pitäisi tuottaa myös suuri nettoenergiasato. Nettoenergia saadaan, kun tuotoksesta vähennetään panos. Tämän tutkimuksen tavoitteena oli selvittää Suomessa yleisesti viljeltävien kasvien energiasuhde ja nettoenergia.

Suomessa on mahdollista viljellä monenlaisia kasveja, mutta tähän tarkasteluun otettiin vain sellaisia, joiden tiedetään kokemuksen perusteella soveltuvan talousviljelyyn. Ohraa, vehnää, perunaa ja sokerijuurikasta voidaan käyttää etanolin raaka-aineena. Rypsistä voidaan valmistaa biodieseliä ja ruokohelpi soveltuu polttoon. Säilörehunurmea voidaan käyttää ensisijaisesti biokaasun raakaaineena. Biokaasun tuotantoon soveltuvat säilörehunurmen lisäksi myös muut edellä mainitut kasvit.

Parhaillaan tutkitaan maissin, hampun sekä monien palkokasvien soveltumista energiantuotantoon. On vielä ennenaikaista sanoa, täyttääkö jokin näistä kasveista hyvän energiakasvin vaatimukset. Hyvän sadonmuodostuskyvyn lisäksi energiakasvin pitää olla viljelyvarma. Energiantuotantoa ei voida perustaa koeoloissa joinain vuosina havaittuihin korkeisiin energiasatoihin, koska energiantuotantoketjun pitää toimia luotettavasti käytännön oloissa vuodesta toiseen. Sato pitäisi pystyä korjaamaan ja varastoimaan pienin kustannuksin, koska bioenergian pitää vielä pitkään kilpailla hinnasta fossiilisten polttoaineiden kanssa. Korkea hinta on tärkein este biopolttoaineiden yleistymiselle.

\section{Aineisto ja menetelmät}

Tarkasteltaviksi kasveiksi valittiin ohra, kevätvehnä, rypsi, peruna, sokerijuurikas, ruokohelpi ja säilörehunurmi. Tärkein valintakriteeri oli käytännön viljelyssä todettu viljelyvarmuus. Viljelyvarmuuden lisäksi mukaan haluttiin ottaa joukko kasveja, jotka soveltuvat lämmön, nestemäisen liikennepolttoaineen tai biokaasun tuottamiseen. Valituista kasveista ruokohelpi on uusi tulokas, mutta senkin viljelystä on jo kokemusta yli kymmenen vuoden ajalta tuhansien hehtaarien alalla. Ruokohelpi on tärkeä myös siksi, että se on ainoa varsinainen energiakasvi. Muita kasveja viljellään ensisijaisesti ravinto- ja rehukäyttöön.

Tarkasteltava systeemi rajattiin siten, että mukaan otettiin tuotantoon tarvittavat suorat ja epäsuorat energiapanokset lukuun ottamatta rakennuksista, pelloista ja infrastruktuurista aiheutuvia energiapanoksia. Jokaiselle kasville rakennettiin oma energiatasemalli, joka sisälsi tarpeelliset työvaiheet ja tuotantotarvikkeet. Taulukossa 1 on esitetty mallien tärkeimpiä lähtöarvoja. Ohran, vehnän ja rypsin tuotantoketju katsottiin päättyneeksi, kun sato oli kuivattu. Säilörehu oletettiin korjattavan kaksi kertaa kaudessa ja säilöttävän pyöröpaaleihin. Ruokohelpi oletettiin paalattavan pyöröpaaleihin ja säilöttävän pellon laidalla. Perunan ja sokerijuurikkaan korjuuketju päättyi aumaan, joka sijaitsi puolen kilometrin etäisyydellä pellosta. Taulukko 2 esittää satojen kosteuden ja sijainnin tarkastelun päättyessä. Sadon energiasisällöksi laskettiin kuiva-aineen alempi lämpöarvo (Lower Heating Value = LHV).

Energiapanoksia käsiteltiin primäärienergiana eli energian hankkimiseen käytetty energia ja energian tuotannon häviöt otettiin huomioon aina, kun se oli mahdollista. Menettely ei ollut kuitenkaan täysin systemaattista, koska kirjallisuudessa ei aina kerrottu, kummasta energiasta oli kyse. 
Taulukko 1. Energiatasemallien lähtöarvoja (Mikkola \& Ahokas 2009).

\begin{tabular}{|c|c|c|c|}
\hline $\begin{array}{l}\text { Työvaihe tai tuotanto- } \\
\text { hyödyke }\end{array}$ & $\begin{array}{l}\text { Dieselpolttoaineen kulu- } \\
\text { tus tai tuotantohyödyk- } \\
\text { keen valmistuksen ener- } \\
\text { gian kulutus }\end{array}$ & Yksikkö & $\begin{array}{l}\text { Lähde- } \\
\text { kirjallisuus }\end{array}$ \\
\hline \multicolumn{4}{|l|}{ Perusmuokkaus } \\
\hline - kyntö & 25,1 & 1 diesel-pa ha ${ }^{-1}$ & $1,2,3,4,7$ \\
\hline - sänkimuokkaus (1 kerta) & & & \\
\hline o piikkikultivaattori & 10,0 & I diesel-pa ha & 3 \\
\hline o lautasmuokkain & 7,2 & 1 diesel-pa ha ${ }^{-1}$ & 1,7 \\
\hline \multicolumn{4}{|l|}{ Kylvömuokkaus } \\
\hline - tasausäestys & 4,5 & 1 diesel-pa ha ${ }^{-1}$ & 2 \\
\hline - äestys (1 kerta) & 5,4 & 1 diesel-pa ha ${ }^{-1}$ & $1,2,3,4$ \\
\hline \multicolumn{4}{|l|}{ Kylvö } \\
\hline - kylvölannoitus & 3,7 & 1 diesel-pa ha ${ }^{-1}$ & 2,3 \\
\hline - suorakylvö & 7,6 & 1 diesel-pa ha- ${ }^{-1}$ & 1,3 \\
\hline Pintalannoitus & 2,9 & 1 diesel-pa ha ${ }^{-1}$ & 1,4 \\
\hline Ruiskutus & 1,8 & 1 diesel-pa ha ${ }^{-1}$ & $1,2,3,4$ \\
\hline Puinti & 15,1 & 1 diesel-pa ha ${ }^{-1}$ & $1,2,5$ \\
\hline Viljan kuivaus & 120,0 & $\begin{array}{l}\text { (g diesel-pa)/haihdutettu } \\
\text { vesi-kg }\end{array}$ & 6 \\
\hline Niitto & 6,0 & 1 diesel-pa ha ${ }^{-1}$ & 1,4 \\
\hline Pyöröpaalaus & 0,5 & 1 diesel-pa/paali & 1 \\
\hline Peltokuljetus & 76,0 & (g diesel-pa)/tonni ja km & 1 \\
\hline Typpi alkuaineena & 49,2 & $\mathrm{MJ} \mathrm{kg}^{-1}$ & 8 \\
\hline Fosfori $\mathrm{P}_{2} \mathrm{O}_{5}$ :na & 15,5 & $\mathrm{MJ} \mathrm{kg}^{-1}$ & 8 \\
\hline Kalium $\mathrm{K}_{2} \mathrm{O}$ :na & 9,7 & $\mathrm{MJ} \mathrm{kg}^{-1}$ & 8 \\
\hline Torjunta-aine & 273,6 & $\mathrm{MJ} \mathrm{kg}^{-1}$ & 8 \\
\hline Kalkki & 1,3 & $\mathrm{MJ} \mathrm{kg}^{-1}$ & 9 \\
\hline
\end{tabular}

Lähteet:

1) Ermittlung des Kraftstoffverbrauchs in der Land- und Forstwirtschaft 2005. Österreichisches Kuratorium für Landtechnik und Landentwicklung.

2) Palonen, J. \& Oksanen, E. H. 1993

3) Danfors, B. 1988. (N.B. Fuel consumption multiplied with 1.2 in order take into account driving at headland.)

4) Rinaldi, M., Erzinger, S., \& Stark, R. 2005

5) Kalk, W.-D. \& Hülsbergen, K.-J. 1999

6) Suomi, P., Lötjönen, T., Mikkola, H., Kirkkari, A.-M., \& Palva, R. 2003.

7) McLaughlin, N. B., Drury, C. F., Reynolds, W. D., Yang, X. M., L, Y. X., Welacky, T. W. \& Stewart, G. 2008

8) Edwards, R., Larivé, J.-F., Mathieu, V. \& Rouveirolles, P. 2006

9) Helsel, Z. R. 1992, Börjesson, P. I. I. 1996, West, T., O. \& Marland, G. 2002

Taulukko 2. Sadon vesipitoisuus ja sijainti energiatarkastelun lopussa (Mikkola \& Ahokas 2009).

\begin{tabular}{|c|c|c|c|c|}
\hline Viljelykasvi & $\begin{array}{l}\text { Korjattu } \\
\text { sato }\end{array}$ & $\begin{array}{l}\text { Sadon vesi- } \\
\text { pitoisuus tarkaste- } \\
\text { lun lopussa, } \\
\% \text { w.b. }\end{array}$ & $\begin{array}{l}\text { Kuiva-aineen } \\
\text { alempi läm- } \\
\text { pöarvo, } \\
\text { MJ kg-1 }\end{array}$ & $\begin{array}{l}\text { Sadon sijainti ja varastointi- } \\
\text { muoto tarkastelun lopussa }\end{array}$ \\
\hline Ohra & Siemenet & 14 & 18,7 & Tilalla kuivattuna siilossa. \\
\hline Kevätvehnä & Siemenet & 14 & 18,7 & Tilalla kuivattuna siilossa. \\
\hline Rypsi & Siemenet & 9 & 26,4 & Tilalla kuivattuna siilossa. \\
\hline Ruokohelpi & Koko kasvusto & 15 & 17,6 & $\begin{array}{l}\text { Pyöröpaalit pinottuna pellon lai- } \\
\text { dalla ja suojattuna sateelta. }\end{array}$ \\
\hline Säilörehunurmi & Koko kasvusto & 68 & 17,6 & $\begin{array}{l}\text { Pyöröpaalit muoviin kiedottuna } \\
\text { pellon laidalla. Säilöntäainetta on } \\
\text { käytetty paalauksen yhteydessä. }\end{array}$ \\
\hline Peruna & Mukulat & 77 & 18,7 & Aumassa pellon laidalla. \\
\hline Sokerijuurikas & Juurikkaat & 78 & 18,7 & Aumassa pellon laidalla. \\
\hline
\end{tabular}


Alustavan tarkastelun sekä VTT:n ja MTT:n tutkimuksen (Mäkinen et al. 2006) perusteella oli heti todettavissa, että typpilannoitteen valmistus on yleensä suurin yksittäinen energiapanos. Typpi on myös keskeinen sadon määrään vaikuttava tekijä, ja siksi energiasuhdetta ja nettoenergiaa tarkasteltiin typpilannoituksen funktiona. Hildén et al. (2007) esittämät ohran, kevätvehnän ja rypsin typpivastefunktiot skaalattiin siten, että tulokseksi saatiin keskimääräisillä typpimäärillä sato, joka vastasi Suomen keskimääräistä satoa kaudella 1990 - 2006 (TIKE 2007). Ilman skaalausta sadot olisivat olleet huomattavasti keskimääräistä korkeampia. Säilörehulle käytettiin Hiivolan et al. (1974) esittämiä typpivastefunktioita. Ruokohelven typpivastefunktio johdettiin Saijonkari-Pahkalan (2001) esittämien kenttäkoetulosten perusteella ja skaalattiin vastaamaan käytännön viljelysatoja. Perunalle ja sokerijuurikkaalle ei ollut typpivastefunktioita saatavissa ja siksi niille laskettiin sato vain yhdellä, keskimääräisellä typpimäärällä, joka oli perunalle $70 \mathrm{~kg} \mathrm{ha}^{-1}$ ja sokerijuurikkaalle $120 \mathrm{~kg} \mathrm{ha}^{-1}$. Taulukossa $3 \mathrm{on}$ esitetty alkuperäiset ja skaalatut typpivastefunktiot.

Taulukko 3. Typpivastefunktiot, joita on käytetty sellaisenaan tai skaalauksen jälkeen ohran, kevätvehnän, rypsin, ruokohelven ja säilörehun sadon laskentaan (Mikkola \& Ahokas 2009).

\begin{tabular}{|c|c|c|c|c|}
\hline$\overline{\text { Kasvi }}$ & $\begin{array}{l}\text { Kosteus, } \\
\text { \% w.b. }\end{array}$ & Typpivastefunktio & Lähde & Skaalattu funktio \\
\hline Ohra & 15 & $y=-0,1305 N^{2}+35,697 N+3275$ & Hildén et al. 2007 & $\begin{array}{l}y=-0,1305 N^{2}+35,697 N+ \\
1275\end{array}$ \\
\hline $\begin{array}{l}\text { Kevätvehnä } \\
\text { Rypsi }\end{array}$ & $\begin{array}{l}15 \\
8\end{array}$ & $\begin{array}{l}y=-0,089 N^{2}+32,33 N+2536 \\
y=-0,026 N^{2}+12,57 N+1034\end{array}$ & $\begin{array}{l}\text { Hildén et al. } 2007 \\
\text { Hildén et al. } 2007\end{array}$ & $\begin{array}{l}y=-0,089 N^{2}+32,33 N+1387 \\
y=-0,026 N^{2}+12,57 N+627\end{array}$ \\
\hline Ruokohelpi & 0 & $y=-0,1137 N^{2}+38,703 N+6172$ & 1) & $\begin{array}{l}y=-0,0853 N^{2}+29,028 N+ \\
4628,9\end{array}$ \\
\hline $\begin{array}{l}\text { Säilörehu- } \\
\text { nurmi }\end{array}$ & 0 & $\begin{array}{l}\text { 1. korjuu: } \\
y=-0,084 * N^{2}+26,9 * N+992 \\
\text { 2. korjuu: } \\
y=-0,098 * N^{2}+28,73 * N+764\end{array}$ & $\begin{array}{l}\text { Hiivola et al. } \\
1974\end{array}$ & $\begin{array}{l}\text { 1. korjuu: } \\
y=-0,084 * N^{2}+26,9 * N+992 \\
\text { 2. korjuu: } \\
y=-0,098 * N^{2}+28,73 * N \\
+764\end{array}$ \\
\hline
\end{tabular}

1) Kirjoittajien johtamafunktio Saijonkari-Pahkalan (2001) esittämän kenttäkoeaineiston perusteella.

\section{Tulokset ja tulosten tarkastelu}

Kuvassa 1 on esitetty panosenergian kokonaismäärä ja jakauma ohran, säilörehunurmen ja sokerijuurikkaan viljelyssä. Kuvan 1 esittämässä tapauksessa typpimäärät olivat ohralle $80 \mathrm{~kg} \mathrm{ha}^{-1}$, säilörehunurmelle $180 \mathrm{~kg} \mathrm{ha}^{-1}$ ja sokerijuurikkaalle $120 \mathrm{~kg} \mathrm{ha}^{-1}$. Maatalouskemikaalien (lannoitteet, kalkki, torjunta-aineet) osuus on hallitseva ja niistä aivan erityisesti lannoitetyppi. Koneet ja niiden polttoaine ovat seuraavaksi suurin energiapanos. Säilörehun tuotannossa kiedontamuovi on suhteellisesti samaa luokkaa kuin kuivaus ohran tuotannossa, mutta absoluuttisesti kiedontamuovi on suurempi energiapanos.
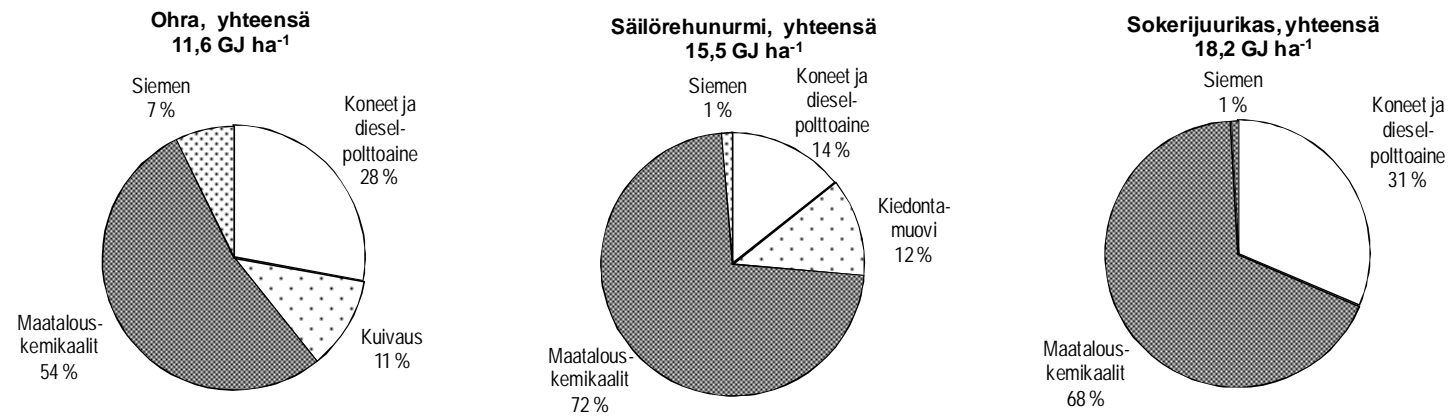

Kuva 1. Panosenergian kokonaismäärä ja sen jakauma ohran, säilörehunurmen ja sokerijuurikkaan viljelyssä (Mikkola \& Ahokas 2009). 
Kuvassa 2 on esitetty ohran, kevätvehnän, rypsin, ruokohelven ja säilörehunurmen energiataseet ja nettoenergiat. Energiasuhteelle on tyypillistä, että se lähtee alenemaan heti, kun kasvustoa aletaan lannoittaa, tai nousee aluksi hieman ja laskee loivasti sen jälkeen. Korkea energiasuhde saavutetaan lannoittamatta tai alhaisilla typpilannoitusmäärillä. Jatkuva energiakasvin viljely ilman typpilannoitusta ei kuitenkaan ole kestävä vaihtoehto, koska se köyhdyttäisi maaperää vähentämällä maan eloperäisen aineksen määrää (Blair et al. 2006a, Blair et al. 2006b). Pitkällä aikavälillä sadon määrä vähenisi ja maan viljelykunto heikkenisi. Käytännön typpilannoitusmäärät ovat ohran, kevätvehnän ja rypsin viljelyssä lähellä energiasuhteen optimia ja ruokohelven ja säilörehunurmen viljelyssä jonkin verran optimia suurempia. Mahdollisimman suuren nettoenergian tavoittelu edellyttäisi hyvin voimaperäistä viljelyä. Typpilannoitusmäärät olisivat tällöin ympäristötuen 2007 - 2013 ehtojen (MAVI 2009) ylärajoilla tai jopa niitä suurempia. Käytännön viljelyssä tavoitellaan taloudellista optimia, joka näyttäisi tällä hetkellä olevan lähempänä energiasuhteen kuin nettoenergian optimia.

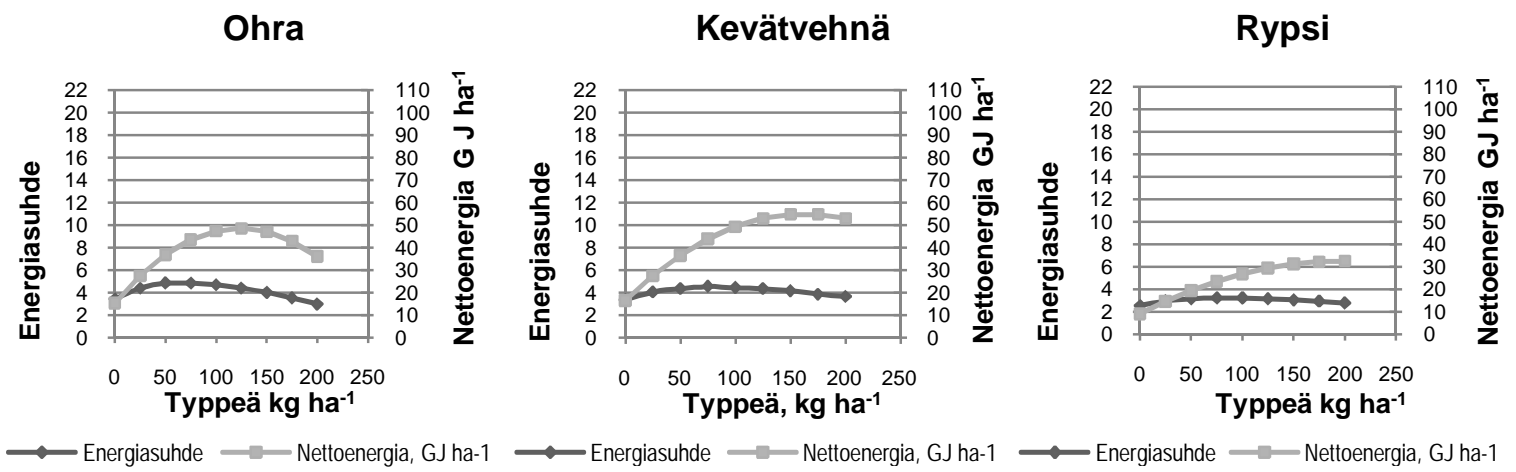

Ruokohelpi

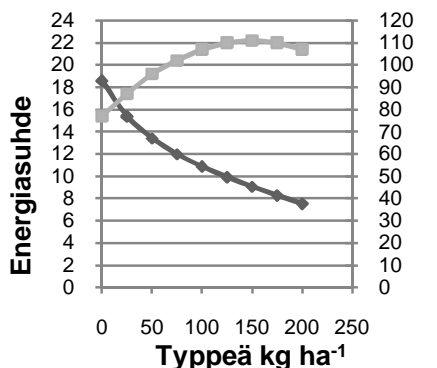

Typpeä kg ha-1
Säilörehunurmi

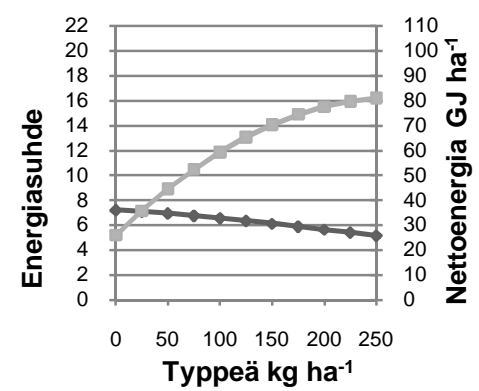

$\longrightarrow$ Energiasuhde $\longrightarrow$ Nettoenergia, GJ ha-1

Kuva 2. Ohran, kevätvehnän, rypsin, ruokohelven ja säilörehunurmen energiasuhteet ja nettoenergiat typpilannoituksen funktiona (Mikkola \& Ahokas 2009).

Ruokohelven energiasuhde ja nettoenergia olivat ylivoimaisia ohraan, kevätvehnään ja rypsiin verrattuna ja säilörehunurmeenkin verrattuna selvästi korkeampia. Ruokohelpi sopii energiakasviksi, koska se on monivuotinen, vuotuisia työvaiheita on vähän, sadon varastointi on yksinkertaista ja kuiva-ainesato on suuri. Kuvassa 3 on verrattu ruokohelpeä perunaan ja sokerijuurikkaaseen. Sokerijuurikkaasta saadaan yhtä suuri nettoenergia kuin ruokohelvestä, mutta sokerijuurikkaan energiasuhde on huonompi. Perunan energiasuhde ja nettoenergia ovat alempia kuin ruokohelven ja sokerijuurikkaan. Viljeltävyyden näkökulmasta ruokohelpi on selvästi vaatimattomampi kuin peruna ja sokerijuurikas. Lisäksi pitää ottaa huomioon, että energiatarkastelun päättyessä peruna ja sokerijuurikas olivat varastoituina aumassa pellon laidalla. Kumpikaan sato ei kestä varastointia muutamaa viikkoa pitempään, kun taas muita tarkasteltuja kasveja voitaisiin varastoida ainakin vuosi (säilörehu) tai pitempään (ohra, kevätvehnä, rypsi ja ruokohelpi). 

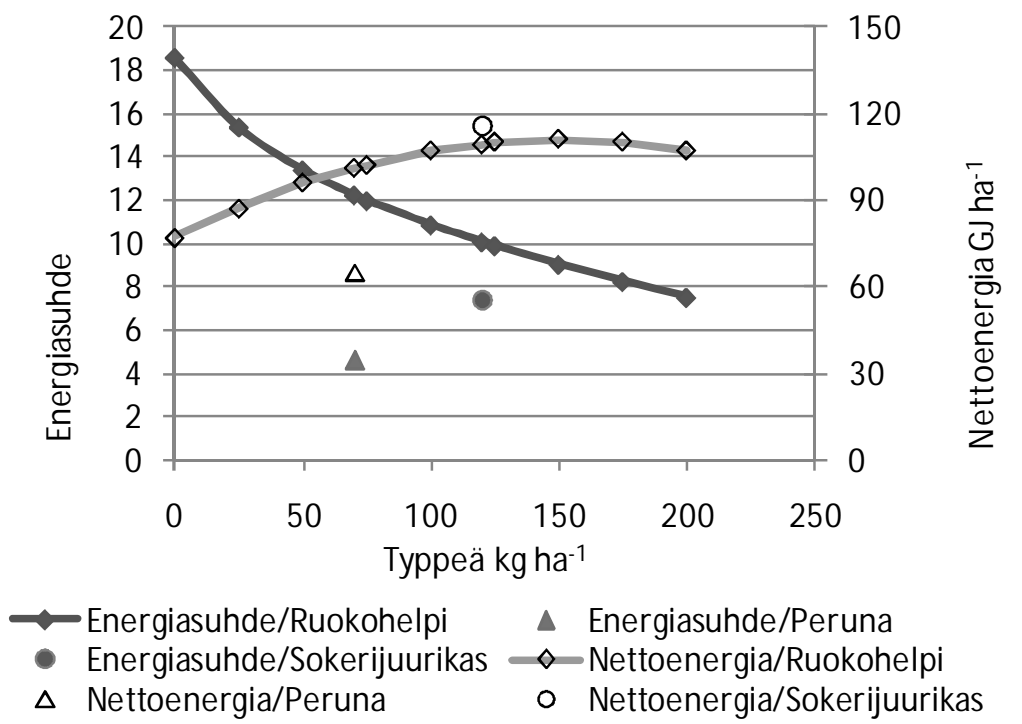

Kuva 3. Ruokohelven energiasuhde ja nettoenergia verrattuna sokerijuurikkaaseen ja perunaan (Mikkola \& Ahokas 2009) .

Ruotsalainen Börjesson (1996) on analysoinut samojen kasvien energiasuhteet ja nettoenergiat kuin tässäkin tutkimuksessa ja päätynyt kautta linjan hieman korkeampiin arvoihin. Ruotsin paremmat sadot selittävät todetut erot.

\section{Johtopäätökset}

Ruokohelven energiasuhde oli korkein ja ruokohelpi tuotti yhtä paljon nettoenergiaa kuin sokerijuurikas. Myös säilörehunurmen energiasuhde ja nettoenergia olivat suhteellisen korkeita ja korkeampia kuin ohran, kevätvehnän tai rypsin. Korkea energiasuhde saavutettiin ilman typpilannoitusta tai kohtuullisilla lannoitusmäärillä. Viljely ilman typpilannoitusta vähentäisi kuitenkin pitkällä aikavälillä maan eloperäisen aineksen määrää ja huonontaisi maan viljelykuntoa. Siksi kohtuullinen typpilannoitus on suositeltavaa, vaikka parasta energiasuhdetta ei saavutettaisikaan.

Suuri nettoenergiasato edellyttäisi puolestaan voimaperäistä viljelyä ja suuria typpilannoitusmääriä. Optimaalinen energiasuhde ja suuri nettoenergiasato ovat siis typpilannoituksen näkökulmasta ristiriitaisia tavoitteita. Käytännön viljelyssä päätavoite on kuitenkin hyvä taloudellinen tulos ja tämän hetken hintasuhteilla lannoitus on lähempänä energiasuhteen kuin nettoenergian optimia. Koska typpilannoitteen tuottaminen vaatii paljon energiaa, energian hinta vaikuttaa suoraan myös typpilannoitteen hintaan. Jos energian ja typpilannoitteen hintasuhde ei olennaisesti muutu, käytännön lannoitus säilynee tasolla, joka on lähellä energiasuhteen optimia.

Energiasuhteen ja nettoenergian analysointi on menetelmä, joka paljastaa tuotantoketjun paljon energiaa kuluttavat työvaiheet ja tuotantotarvikkeet. Kun suurimmat energiankulutuskohteet on tunnistettu, voidaan harkita, onko jotain tehtävissä energiankulutuksen vähentämiseksi. Menetelmää kannattaa käyttää valittaessa kasveja bioenergiatutkimuksiin. Jo alustavan analyysin avulla on mahdollista seuloa parhaat ehdokkaat jatkotutkimuksiin. Hyvän energiakasvin tunnusmerkkejä ovat monivuotisuus, pieni typpilannoitustarve, suuri kuiva-ainesato sekä korjuu ja varastointi, joka ei edellytä kuivausta tai muita paljon energiaa kuluttavia työvaiheita.

\section{Kirjallisuus}

Blair, N., Faulkner, R. D., Till, A. R. \& Poulton, P. R. 2006a. Long-term management impacts on soil C, N and physical fertility. Part I: Broadbalk experiment. Soil \& Tillage Research 91: 30 - 38.

一, Faulkner, R. D., Till, A. R., Korschens, M. \& Schulz, E. 2006b. Long-term management impacts on soil C, N and physical fertility. Part II: Bad Lauchstadt static and extreme FYM experiments. Soil \& Tillage Research 91: 39 - 47. 
Börjesson, P. I. I. 1996. Energy analysis of biomass production and transportation. Biomass and Bioenergy 11: 305-318.

Danfors, B. 1988. Bränsleförbrukning och avverkning vid olika system för jordberabetning och sådd. Jordbrukstekniska Institutet, meddelande nr 420.85 p.

Edwards, R., Larivé, J.-F., Mathieu, V. \& Rouveirolles, P. 2006. Well-To-Wheels analysis of future automotive fuels and powertrains in the European context. Well-To-Tank Report, Version 2b, May 2006. pdf-dokumentti, luettu 6.6.2008.

http://www.senternovem.nl/mmfiles/Well_to_Tank_Report_EU_tcm24-195171.pdf

Ermittlung des Kraftstoffverbrauchs in der Land- und Forstwirtschaft 2005. Osterreichisches Kuratorium für Landtechnik und Landentwicklung. 5 p.

Helsel, Z. R. 1992. Energy and alternatives for fertilisers and pesticide use. In: Fluck, R. C., editor. Energy in farm production. Vol. 6. In: Stout, B. A., editor. Energy in world agriculture. Amsterdam: Elsevier; 1992.

Hiivola, S.-L., Huokuna, E. \& Rinne, S.-L. 1974. The effect of heavy nitrogen fertilization on the quantity and quality of yields of meadow fescue and cocksfoot. Annales Agriculturae Fenniae 13: 149-160.

Hildén, M., Huhtala, A., Koikkalainen, K., Ojanen, M., Grönroos, J., Helin, J., Isolahti, M., Kaljonen, M., Kangas, A., Känkänen, H., Puustinen, M., Salo, T., Turtola, E. \& Uusitalo, R. 2007. Verotukseen perustuva ohjaus maatalouden ravinnepäästöjen rajoittamisessa. Ympäristöminiseriön raportteja 15. $73 \mathrm{~s}$.

Kalk, W.-D. \& Hülsbergen, K.-J. 1999. Dieselkraftstoffeinsatz in der Pflanzenproduktion. Landtechnik 54: $332-333$.

MAVI 2009. Opas ympäristötuen ehtojen mukaiseen lannoitukseen 2007 - 2013. Maaseutuviraston julkaisusarja: Hakuoppaita ja -ohjeita. $27 \mathrm{~s}$.

McLaughlin, N. B., Drury, C. F., Reynolds, W. D., Yang, X. M., Li, Y. X., Welacky, T. W. \& Stewart, G. 2008. Energy Inputs for Conservation and Conventional Primary Tillage Implements in a Clay Loam Soil. Transactions of the ASABE 51: 1153-1163.

Mikkola, H. J. \& Ahokas, J. 2009. Energy ratios in Finnish agricultural production. Agriculture and Food Science, Vol. 18(2009). In press.

Mäkinen, T., Soimakallio, S., Paappanen, T., Pahkala, K., Mikkola, H. J. 2006. Liikenteen biopolttoaineiden ja peltoenergian kasvihuonekaasutaseet ja uudet liiketoimintakonseptit. VTT tiedotteita 2357: 134 s. + liitt. 19 s. http://www.vtt.fi/inf/pdf/tiedotteet/2006/T2357.pdf

Palonen, J. \& Oksanen, E. H. 1993. Labour, machinery and energy data bases in plant production. Työtehoseuran julkaisuja 330. 106 p.

Rinaldi, M., Erzinger, S., \& Stark, R. 2005. Treibstoffverbrauch und Emissionen von Traktoren bei landwirtschaftlichen Arbeiten. FAT-Schriftenreiche Nr. 65. 92 p.

Saijonkari-Pahkala, K. 2001. Non-wood plants as raw material for pulp and paper. Agricultural and Food Science in Finland 10, Supplement1: 101 p. Diss.: Helsingin yliopisto, 2001. (Doctoral Dissertation). http://www.mtt.fi/afs/pdf/mtt-afsf10_suppl1.pdf

Suomi, P., Lötjönen, T., Mikkola, H., Kirkkari, A.-M. \& Palva, R. 2003. Viljan korjuu ja varastointi laajenevalla viljatilalla. Maa- ja elintarviketalouden tutkimuskeskus. Maa- ja elintarviketalous $31.100 \mathrm{~s}$.

TIKE 2007. Yearbook of farm statistics 2007. Information Centre of the Ministry of Agriculture and Forestry, TIKE. 267 p. 